Nova Southeastern University

From the SelectedWorks of Debra Moss Vollweiler

Fall 2018

\title{
Don't Panic! The Hitchhiker's Guide to Learning Outcomes: Eight Ways to Make Them More Than (Mostly) Harmless
}

Debra Moss Vollweiler, Nova Southeastern University - Shepard Broad College of Law 


\section{University of Dayton}

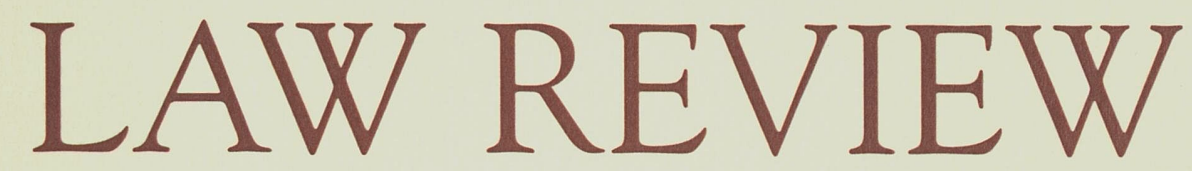

Don't Panic! The HitchHiker's Guide To Learning Outcomes: Eight Ways to Make Them More Than (Mostly) Harmless DEBRA MOSS VOLLEWEILER 


\section{HEINONLINE}

Citation:

Debra Moss Vollweiler, Don't Panic: The Hitchhiker's

Guide to Learning Outcomes: Eight Ways to Make Them

more than (Mostly) Harmless, 44 U. Dayton L. Rev. 17

(2018)

Provided by:

NSU Shepard Broad College of Law Panza Maurer Law Library

Content downloaded/printed from $\underline{\text { HeinOnline }}$

Thu May 30 13:09:17 2019

-- Your use of this HeinOnline PDF indicates your

acceptance of HeinOnline's Terms and Conditions

of the license agreement available at

https://heinonline.org/HOL/License

-- The search text of this PDF is generated from uncorrected OCR text.

-- To obtain permission to use this article beyond the scope of your HeinOnline license, please use:

\section{Copyright Information}

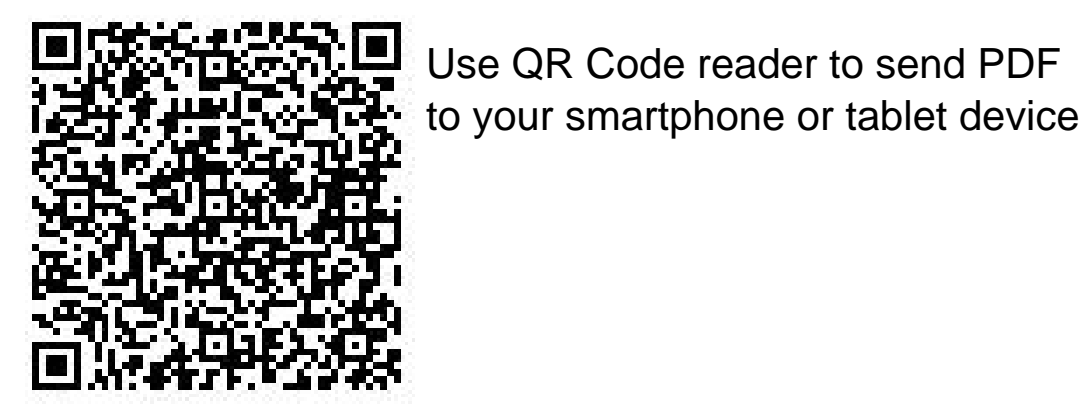




\title{
DON'T PANIC! THE HITCHHIKER'S GUIDE TO LEARNING OUTCOMES: EIGHT WAYS TO MAKE THEM MORE THAN (MOSTLY) HARMLESS
}

\author{
Debra Moss Vollweiler*
}

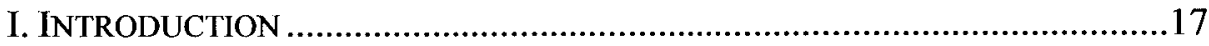

II. PRIMER ON LEARNING OUTCOMES AND ASSESSMENTS ............................20

III. EIGHT SUGGESTIONS TO USE LEARNING OUTCOMES TO .........................25

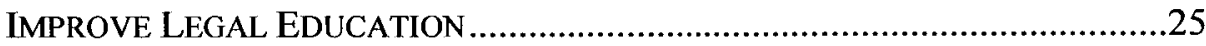

A. Ease into Reverse Planning with Central Planning and Modified

Forward Planning ................................................................25

B. Curriculum Mapping to Ensure Programmatic Learning

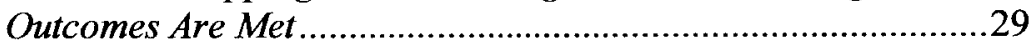

C. Cooperation Among Sections of Same Course and Vertically

Through Curriculum.................................................................32

D. Tying Course Evaluations to Learning Outcomes to Measure

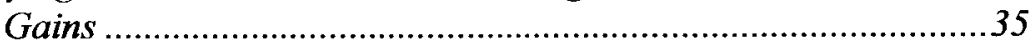

E. Expanding the Idea of What Outcomes Can be for Legal

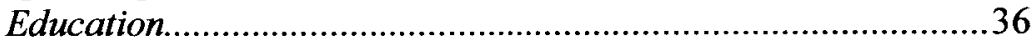

F. Better use of Formative Assessments for Measurement of

Competencies.

G. Use of the Bar Exam to Appropriately Measure Learning

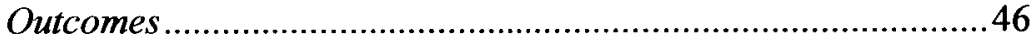

H. Properly Leverage Data on Assessments Through Collection

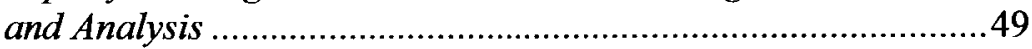

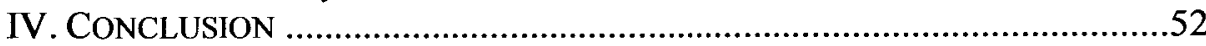

\section{INTRODUCTION}

Legal education professors and administrators at law schools nationwide have finally been thrust into the world of educational and curriculum planning. Ever since ABA Standards started requiring law schools to "establish and publish learning outcomes"1 designed to achieve their objectives, legal education has turned itself upside down in efforts to

* Debra Moss Vollweiler, a/k/a Debra Moss Curtis is the Associate Dean for Academic Affairs at the NSU Shepard Broad College of Law.

1 ABA Standards and Rules of Procedure for Approval of Law Schools 2017-2018, ABA Standard 301, https:/www.americanbar.org/content/dam/aba/publications/misc/legal_education/Standards/20182019ABAStandardsforApprovaloflawSchools/2018-2019-aba-standards-chapter3.pdf (last visited Sept. 28, 2018) 
comply. $^{2}$ However, in the initial stages of these requirements, many law schools may have viewed these requirements as "boxes to check" to meet the standard, rather than wholeheartedly embracing these reliable educational tools that have been around for decades.

Much has been written in recent years in the legal scholarship world on these standards and the potential impact on a variety of areas of legal education, including faculty workload, curriculum, and costs to law schools. ${ }^{3}$ However, requiring faculty to use these curricula, strategies, or assessments are not a novel problem for law professors in the world of higher education. ${ }^{4}$ In the fields of professional education, dental schools led the way by adopting outcome measures in 1988, and most professional schools have since followed. ${ }^{5}$ Legal education is firmly and reluctantly, in many cases, bringing up the rear.

However, given that most faculty teaching in law schools have a Juris Doctorate and not education degrees, the task of bringing thousands of law professors up to speed on the design, use, and measurement of learning outcomes to improve education is a daunting one. Unfortunately, as the motivation to adopt them for many schools was merely meeting the standards, many law schools have opted for technical compliance. Some law Schools likely have begun incorporating this work into self-study or accreditation visit committees to manage assessment planning and learning outcomes to ensure the school gets through their accreditation process, rather than for the purpose of truly enhancing the educational experience for students.

There are many challenges to improving the program for students through learning outcomes, but it must begin with a perspective and culture change within a law school. Law professors often confuse teaching and learning. Teaching has been defined as "the act of giving lessons on a subject" while learning is "knowledge gained through study[,]" which can be of information, skills, behaviors, or values. ${ }^{6}$ There are those who believe "if the learner didn't learn, then the teacher didn't teach[,]" but unfortunately, this is often the opposite of how law professors view their classrooms. ${ }^{7}$ For those professors stuck in a "teacher centric" world, teaching is analogous to

2 See generally Andrea Curcio, A Simple Low-Cost Institutional Learning-Outcomes Assessment Process, 67 J. LEGAL ED. 489 (2018).

${ }^{3}$ Casandra L. Hill, The Elephant in the Law School Assessment Room: The Role of Student Responsibility and Motivating Our Students to Learn, 56 How. L.J. 447, 449 (2013)

${ }^{4}$ Suzanne M. Wilson \& Penelope L. Peterson, Theories of Learning and Teaching What Do They Mean for Educators? 14, NATIONAL EDUCATION ASSOCIATION (July 2006), http:/www.nea.org/assets/ docs/mf Itreport.pdf

5 Janet W. Fisher, Putting Students at the Center of Legal Education: How an Emphasis out Outcome Measure in the ABA Standards for Approval of Law Schools Might Transform the Educational Experience of Law Schools, 35 S. ILL. U. L.J. 225, 228 (2011).

${ }^{6}$ Koshal, Difference Between Teaching and Learning, DiffERENCEBETwEEN.COM (Aug. 31, 2011), http://www.differencebetween.com/difference-between-teaching-and-vs-learning/.

7 Neal a. Whitman, David C. Spendlove, \& Clair H. Clark, InCreasing Students' LEARNING: A FACULTY GUIDE TO REDUCING STRESS AMONG STUDENTS 5 (1989). 
giving - if something is given, something must be received. ${ }^{8}$ That perspective must be flipped for real improvement to begin.

Another obstacle to overcome is simple resistance by faculty to change, which may have many sources, including human behavior and the institutional culture of a school. ${ }^{9}$ In law schools, much of this resistance comes merely from faculty being anti-administration, anti-regulation, or antianything that infringes on their long-held belief of independence. The fact is that many faculty members will reluctantly submit to what they see as administrative burdens on their teaching, but that is not the same as them embracing concepts as tools for improvements. As a result, there is no question that there are faculty who are willing to technically comply with the concept of learning outcomes and using assessments to measure them but have not embraced them in their teaching.

For those law schools reluctantly trailing along on the learning outcome and assessment train, the best advice to schools thrown into this world comes from the Hitchhiker's Guide to the Galaxy comedy science fiction series, in which the electronic guide tells those along for the ride "Don't Panic!" (in large friendly letters) while describing our home planet as a whole, at least for part of the series, as "mostly harmless." 10 While schools should not be panicking at implementing and measuring learning outcomes, neither should they consign the tool to be a "mostly harmless" one that misses out on the opportunity to improve their program of legal education through proper leveraging. Understanding that outcome design and appropriate assessment design is itself a scholarly, intellectual function that requires judgment, knowledge, and skill by faculty can dictate a path of adoption that is thoughtful and productive.

One scholar has boiled the learning outcome charge down to two clear questions: "What does your law school want your students to know and be able to do when they graduate?" and "How will you know that your students have obtained these competences?"11 However simple these questions seem conceptually, the work that needs to be done to answer them properly and meaningfully is quite complex. But when schools take a bureaucratic approach to answering them, barely scratching the surface, the answer to these questions ends up being "mostly harmless."

Id.

9 See generally Patrick H. Gaughan, Facilitating Meaningful Change Within U.S. Law Schools, 16 U. N.H. L. REV. 243 (2018).

10 See generally Douglas adams, HitchitKer's Guide to the Galaxy (Del Rey Books Mass Market ed. 2005). Note: The entry about Earth in the Guide used to be "harmless" before it was changed, although more information about the planet was submitted, this was all that was left about the planet after editors were done with it.

1 Anthony Niedwiecki, Prepared for Practice? Developing a Comprehensive Assessment Plan for a Law School Professional Skills Program, 50 U.S.F.L. Rev. 245, 247 (2016). 
To overcome this, schools must embrace, and not evade, the concepts embedded in the standards. Schools must overcome the view that these tasks add a burden to their teaching function and instead embrace them as a tool for improving their teaching. Faculty are clearly resistant to the idea of being evaluated through this process and have called it "threatening, insulting, intrusive, and wrong-headed." A faculty's fear that assessment is "a witch hunt" or that they are being asked to kill their own careers with evidence stems from a fundamental misunderstanding of the purpose of assessment and learning outcomes, which must be addressed institutionally for successful implementation. $^{13}$

As pointed out by one scholar on this topic, many years ago the author of the Little Prince stated, "A goal without a plan is just a wish."14 The technical plan law schools need to take for compliance is clear-starting by identifying their mission and developing program learning outcomes, assembling an assessment team, making an assessment plan, mapping their curriculum, identifying outcomes to assess and develop measures for the desired outcomes, determining validity of assessments, and then evaluating the results of these assessments and developing further action plans as needed. ${ }^{15}$ However, having a real working plan for how schools are going to adopt learning outcomes and the appropriate corollary assessments that add value is the key to the entire process.

This article serves as a guide to law schools on devising, using, and measuring learning outcomes and assessments to gain real improvement in the program of legal education. Part II of this article reviews the ABA Standards, the purpose of learning outcomes and assessments, and the potential that can be unlocked. Part III of this article is a series of practical ideas to use when creating a plan for implementing learning outcomes, and Part IV offers conclusions based on findings discussed throughout this article.

\section{PRIMER ON LEARNING OUTCOMES AND ASSESSMENTS}

The ABA Section of Legal Education and Admissions to the Bar offered a guidance memo in June 2015 regarding ABA Standards 301, 302, 314 , and 315 (sections associated with learning outcomes and their

12 Lori A. Roberts, Assessing Ourselves: Confirming Assumptions and Improving Student Learning By Efficiently and Fearlessly Assessing Student Learning Outcomes, 3 DREXEL L. REV. 457, 467 (2011).

${ }_{13} I d$. at 468.

14 Victoria L. VanZandt, Creating Assessment Plans for Introductory Legal Research and Writing Courses, 16 LEGAL WRITING 313, 313 (2010).

${ }_{15}$ Marie Summerlin et al., The Rubric Meets the Road in Law Schools: Program Assessment of Students Learning Outcomes as a Fundamental Way for Law Schools to Improve and Fulfill Their Respective Missions, SOC. SCI. RESEARCH NETWORK (Apr. 7, 2018), available at https://ssm.com/ abstract $=3158461$. 
measurement. ${ }^{16}$ In the memo, introductory explanation as to these rules are offered:

\section{Standard 301. OBJECTIVES OF PROGRAM OF LEGAL EDUCATION}

(a) A law school shall maintain a rigorous program of legal education that prepares its students, upon graduation, for admission to the bar and for effective, ethical, and responsible participation as members of the legal profession.

(b) A law school shall establish and publish learning outcomes designed to achieve these objectives.

Standard 302. LEARNING OUTCOMES

A law school shall establish learning outcomes that shall, at a minimum, include competency in the following:

(a) Knowledge and understanding of substantive and procedural law;

(b) Legal analysis and reasoning, legal research, problemsolving, and written and oral communication in the legal context;

(c) Exercise of proper professional and ethical responsibilities to clients and the legal system; and

(d) Other professional skills needed for competent and ethical participation as a member of the legal profession.

\section{Standard 314. ASSESSMENT OF STUDENT LEARNING}

A law school shall utilize both formative and summative assessment methods in its curriculum to measure and improve student learning and provide meaningful feedback to students.

\section{Standard 315. EVALUATION OF PROGRAM OF LEGAL EDUCATION, LEARNING OUTCOMES, AND ASSESSMENT ( sic) METHODS}

The dean and the faculty of a law school shall conduct ongoing evaluation of the law school's program of legal education, learning outcomes, and assessment methods; and shall use the results of this evaluation to determine the degree of student attainment of competency in the learning outcomes

\footnotetext{
16 Managing Director's Guidance Memo 1, AMERICAN BAR ASS'N, https://www.americanbar.org/ content/dam/aba/administrative/legal_education_and_admissions_to_the_bar/governancedocuments/201 5 learning_outcomes_guidance.authcheckdam.pdf (last visited Sept. $29, \overline{2} 018$ ).
} 
and to make appropriate changes to improve the curriculum. ${ }^{17}$

Dating back to 2008, the ABA began examining how other accrediting bodies used outcome measurements in their work. ${ }^{18}$ The Special Committee on Output Measures "concluded that the Section of Legal Education and Admissions to the Bar should re-examine the current ABA accreditation standards and reframe them, as needed, to reduce their reliance on input measures and instead adopt a greater and more overt reliance on outcome measures." 19 Through further committee work, the standards were adapted and then adopted, thus placing law schools in this new (to them) world of educational language and planning.

According to that guidance memo, "[l] earning outcomes must consist of clear and concise statements of knowledge that students are expected to acquire, skills students are expected to develop, and values that they are expected to understand and integrate into their professional lives."20 These requirements were technically relatively easy to accomplish. It became clear that in the initial wave of this standard rolling out, technical compliance with the guidance allowed for the adoption and publication of learning outcomes for a "school's overall program of legal education" to be accomplished simply by publishing a simple list on a school's website. ${ }^{21}$ You could further refine this list for program certificates or tracks by publishing where these programs are described, and individual course outcomes could be created-mostly out of thin air by faculty without any training - and published on syllabi. ${ }^{22}$

For law schools, these concepts were, initially, not difficult to articulate. Many law schools focused on what they had been doing for many years-placing an emphasis on the substance of doctrinal law, traditionally taught skills including reading, writing, and analysis, and professional ethics. $^{23}$ Furthermore, many schools determined that outcomes for legal education could be measured with two instruments: the bar exam and the Multistate Professional Responsibility Exam (MPRE), both required for admission into almost every state to be a practicing attorney. ${ }^{24}$ Traditionally, these instruments have been used by law schools for purposes of institutional

\footnotetext{
17 ABA Standards and Rules of Procedure for Approval of Law Schools 2017-2018 - Chapter 3: Program of Legal Education 15, 23-24, AMERICAN BAR AsS'N, https://www.americanbar.org/content/ dam/aba/publications/misc/legal education/Standards/2017-2018ABAStandardsforApprovalofLaw Schools/2017_2018_standards_chapter3.authcheckdam.pdf (last visited Sept. 29, 2018).

18 Supra note $1 \overline{6}$, at 3.

19 Id.

20 Id. at 4.

21 Id.

22 Id.

${ }^{23}$ See generally Anthony Niedwiecki, Law Schools and Learning Outcomes: Developing a Coherent Cohesive, and Compreheive Law School Curriculum, 64 CLEV. ST. L. REV. 661 (2016).

${ }^{24}$ See generally NATIONAL CONFERENCE OF BAR EXAMINERS, http://www.ncbex.org (last visited Sept. 29, 2018).
} 
accountability, or to "collect data to prove effectiveness" regarding external benchmarks. ${ }^{25}$ This approach was a blunt hammering out of learning outcomes that allowed law schools to meet their accreditation standards without making any meaningful changes.

Schools have begun to get more sophisticated in their knowledge of learning outcomes, and in their view of what outcomes of legal education could and should be. A 2016 survey demonstrated schools' gradual understanding of the power of learning outcomes to shape legal education. ${ }^{26}$ By this time, law schools had adopted learning outcomes that included "values that students are expected to understand and integrate into their professional lives," "the competency of demonstrating understanding and integration of pro-active professional development toward excellence at the competencies needed to serve clients and the legal system," as well as those regarding developing self-awareness and cross-cultural competency. ${ }^{27}$ Other law schools have included learning outcomes such as teamwork/effective collaboration, professionalism, strong client relationship skills, integrity, honesty, initiative, strong work ethic, diligence, respect for others, and leadership. ${ }^{28}$ These chosen outcomes demonstrate the progress that faculty have made toward understanding what their programs of legal education could accomplish, and the start of plans to accomplish those goals.

Once outcomes for legal education have broadened to include competencies not traditionally measured in law school, it will not be enough to use the doctrinal and analysis based bar exam and the MPRE exam as assessments to evaluate whether these new outcomes are being met under Standard 315. ${ }^{29}$ Assessments that are used in legal education must be aligned with the outcomes for that course or program to determine whether the learning outcomes stated are being met, and sadly, the traditional licensing exams for new attorneys rarely focus on these skills. ${ }^{30}$

In line with that, law schools are rapidly learning that the traditional one-shot final exam given in many courses is not serving the purpose of measuring these new outcomes. As the rest of the education world is generally more aware, assessments are generally considered of two kinds, formative and summative, one meant to give feedback in the process of meeting the learning outcome, and the other to find out at the end of the

\footnotetext{
${ }^{25}$ Denitsa R. Mavrova Heinrich, Teaching and Assessing Professional Communication Skills in Law School, 91 N.D. L. REV. 99, 108 (2015).

${ }^{26}$ Neil Hamilton, Formation of an Ethical Professional ldentity (Professionalism) Learning Outcomes and E Portfolio Formative Assessments, 48 U. PAC. L. REV. 847, 850 (2017).

${ }^{27}$ Id.

28 Id. at 851.

29 Supra note 17 , at 23-24.

30 Debra Moss Curtis, They're Digging in the Wrong Place: How Learning Outcomes Can Improve Bar Exams and Ensure Practice Ready Attorneys, 10 ELON L. REV. 239, 239 (2018).
} 
educational experience if the learning outcome was met. ${ }^{31}$ Formative assessments are on the rise in legal education but are still considered new, innovative, or faddish by many. ${ }^{32}$

Another criticism of this new world focuses on the possible redirection of "resources, attention, and energy" from the scholarly agendas of many law schools. ${ }^{33}$ The misunderstanding about this process stems in part from a misbelief that that assessment and outcomes are only objectively based and that their practicality is at odds with being intellectual or scholarly. ${ }^{34} \mathrm{But}$ by embracing and developing learning outcomes that reflect a school's values and purpose, any school can actually further their agendas and create a more scholarly environment with a true focus on learning in all forms.

Another line of critique stems from further unfamiliarity by the legal education profession regarding assessments and how to use them, which is a true issue as faculty attempt to use them to their full potential. ${ }^{35}$ Roy Stuckey, one of the pioneers of Best Practices in Legal Education, has expressed skepticism that the new standards will have a short-term impact on improving legal education, because although the standards seek to have law schools develop competence in students, neither the schools nor the ABA can properly measure that competence. ${ }^{36}$ However, in the early stages of determining compliance with these standards, efforts toward the process of measurement will meet ABA Standard 315 in evaluating the effectiveness of the program of legal education. ${ }^{37}$ This is somewhat ironic, as few law professors themselves generally count effort toward accomplishments in law school itself.

There is no question that many in legal education "lack training or expertise concerning the meaning, means, and significance of assessment." 38 However, in other non-legal fields, defining and assessing outcomes has been well established, ${ }^{39}$ and it is here where we must look, learn, and adapt. In thinking about improving learning for students, some have embraced the integrated theory of education, containing five elements that operated together

\footnotetext{
31 Amanda Ronan, Every Teacher's Guide to Assessment, EDUDEMIC.COM, http://www.edudemic. $\mathrm{com} /$ summative-and-formative-assessments/ (last visited Sept. 29, 2018).

${ }^{32}$ See generally Curcio, supra note 2.

${ }^{33}$ Mary A. Lynch, Contemporary Issues in Outcomes Based Education: An Evaluation of Ten Concerns About Using Outcomes in Legal Education, 38 WM. MITCHELL L. REV. 976, 986 (2012).

34 Id. at 987.

${ }^{35}$ Curcio, supra note 2 at 489.

${ }^{36}$ Roy Stuckey, Revisiting Langdell: Legal Education Reform and the Lawyer's Craft: The American Bar Association's New Mandates for Teaching Professional Skills and Values: Impact, Human Resources, New Roles for Clinical Teachers and Virtual Worlds, 51 WAKE FoREST L. REV. 259, 262 (2016).

37 Id.

38 Judith Welch Wegner, Contemplating Competence: Three Meditations, 50 VAL. U. L. REV. 676, 704 (2016).

${ }^{39}$ Id. at 706.
} 
to achieve meaningful learning. ${ }^{40}$ The five elements are the teacher, the learner, knowledge theory, educational context, and an evaluation system. ${ }^{41}$ Effective and meaningful learning occurs when a knowledgeable teacher and an engaged learner work together with an understanding of the way people learn, in the proper physical, organizational, and cultural place, with the proper feedback to help the learner progress. ${ }^{42}$ The juxtaposition of elements is more difficult in law school than it seems, as little thought has gone into place as to these concepts traditionally existing already in legal education. The following suggestions collectively addressing each of these elements serve as a guide to start law schools on that path.

\section{EIGHT SUGGESTIONS TO USE LEARNING OUTCOMES TO IMPROVE LEGAL EDUCATION}

\section{A. Ease into Reverse Planning with Central Planning and Modified Forward Planning}

Maximizing student learning should be the goal of legal education. ${ }^{43}$ There is no question that learning outcomes should "play an important role in instruction" ${ }^{44}$ and in the learning process. The basic principle of curriculum design is reverse planning, also known as backward design. ${ }^{45}$ Reverse planning is part of good instructional design the process of planning, teaching, and learning in a systematic way that includes learning objectives, as well as methods to accomplish those goals and assessments to measure them. ${ }^{46}$ Objectives should be set first, identifying the desired results of the course or program, thus driving the methods, materials, and assessments used in them. ${ }^{47}$

It is important to note that this kind of reverse planning needs to happen on many levels, not just the course level. The ABA Standards suggest both large-scale (program wide) assessment, as well as small-scale (course wide) basis. ${ }^{48}$ Large-scale assessments need to be considered broadly, both program wide (degree) and program specific (any programs within the degree). ${ }^{49}$ In designing curriculum, faculty should be aware of both and

40 Alice M. Thomas, Laying the Foundation for Better Student Learning in the Twenty-First Century: Incorporating an Integrated theory of Legal Education into Doctrinal Pedagogy, 6 WD. L. SYMP. J. 49, $82(2000)$.

41 Id. at $82-96$.

42 Id.

43 See Gerald F. Hess, Value of Variety: An Organizing Principle to Enhance Teaching and Learning, 3 ELON L. REV. 65, 66 (2011).

$44 \mathrm{Id}$. at 69 .

${ }_{45}$ See, e.g., Jay McTighe and Grant Wiggins, Understanding by Design Framework, ASCD (2012), https://www.ascd.org/ASCD/pdf/siteASCD/publications/UbD_WhitePaper0312.pdf.

46 Hess, supra note 43 , at $70-71$.

47 Id. at 71 .

48 Charles P. Cercone \& Adam Lamparello, Assessing a Law School's Program of Legal Education to Comply with the American Bar Association's Revised Standards and Maximize Student Attainment of Core Lawyering Competences, 86 UMKC L. REv. 37, 45 (2017).

${ }^{49} \mathrm{Id}$. 
consider all aspects of both.

Program wide outcome assessment is the big picture measurement of competencies heading into the legal profession. ${ }^{50}$ By contrast, program specific assessments may focus on a program wider than an individual course view, as to a specific channel carved into legal education to accomplish specific purposes - such as a legal research and writing program or a clinical program. ${ }^{51}$ By contrast, small-scale assessments must focus on each professor's course or a course taught across multiple sections by various professors. ${ }^{52}$

One method that has been suggested to tackle this multi-level task of setting and evaluating outcomes is a six-step plan, incorporating the following steps:

1. Develop Program Wide Learning Outcomes;

2. Develop Outcome Specific Skills;

3. Incorporate Outcome-Specific Skills into All Syllabi and Grading Rubrics to Enable Course Specific Assessment;

4. Rely on the Outcome-Specific Skills in Faculty Syllabi to Map Outcomes and Outcome-Specific Skills throughout the Curriculum on a Course, Program-Specific, and ProgramWide Basis;

5. Measure Student Attainment of Learning OutcomeSpecific Skills and Overall Program Outcomes;

6. Use this Information to Conduct a Comprehensive Program Assessment. ${ }^{53}$

These steps can help guide law schools in beginning the process of reverse planning. The concept of reverse planning encourages faculty to think about what they want students to accomplish from a particular course, program, or degree, and then carefully plan the instruction to meet those goals. That process can be daunting to law professors, who may be more comfortable with a forward planning process, which is more teacher-centric.

By contrast, forward planning generally starts with planning a syllabus, the methodology of teaching, and then assessments - in that order. ${ }^{54}$ Anecdotally, this is how many law courses are planned - faculty often decide

50 Id. at 46.

51 Id. at $46-47$.

52 Id. at 47.

53 Id. at $48-49$.

54 Jack C. Richards, Curriculum Approaches in Language Teaching: Forward, Central, and Backward Design, RELC JOURNAL, available at http:/joumals.sagepub.com/doi/pdf/10.1177/0033688212473293 (last visited Sept. 29, 2018). 
what to teach and how to teach it, and then towards the end of the semester, write one exam to test it all. For those trained more in doctrine than teaching methodology, this is actually an instinctual way to plan a course-around what you are going to teach, rather than what you want students to learn. However, this process is not the most useful way to effectuate learning, although it may be the easiest way to teach.

Thus, the challenge is the need for a plan to transition law faculty entrenched (from instinct or experience) in forward planning to backward planning and outcome-based education. One solution is to try to meet in the middle - with central planning. Central planning involves neither starting with the syllabus nor the learning outcomes but with the methodology and assessments of the course. ${ }^{55}$ For law professors, backing the cycle up this one step by starting in the middle may help make the planning cycle less intimidating.

One way to do this may be to look at the quizzes and exams a faculty member has previously offered during the course. A final exam from a previous year can often serve as an outline as to what students should be learning in a course. ${ }^{56}$ If this work by the faculty member represents what they believe a student should know and demonstrate at various points throughout and at the end of the course, then it serves as a signpost from which a faculty member can draw the learning outcomes of a course. What do you require and expect from those assessments: Doctrine? Critical reading? Cultural competency to understand and resolve problems? Whatever skills and doctrine needed to succeed on those assessments should be the course's learning outcomes. Next, consider the methodology employed during the course itself: Are presentations required? Teamwork on projects? Selfdirected modules? How you orchestrate the learning in the class also informs the learning outcomes as to what is expected.

From this deep analysis of what you test and how you teach, you now have the course learning outcomes, and information available to students that all of this knowledge and skills are part of this course, and not just the "topic" which they may believe the course is about. To finish the course planning, a professor now creates a syllabus that truly reflects the learning that students are to undertake - not just textbook page numbers, or case names and code sections-but a syllabus that is a true guide to help students meet all those learning outcomes, which to come full circle, will match up to the assessments with which the planning started.

Similarly, others have backed up the planning cycle even further, and successfully leveraged traditional forward planning curriculum by keeping

\footnotetext{
55 Id.

56 Herbert N. Ramy, Moving Students from Hearing and Forgetting to Doing and Understanding: A Mamual for Assessment in Law School, 41 CAP. U. L. REV. 837, 842 (2013).
} 
learning outcomes in mind without locking them down, from the start of planning transactional courses in law school. ${ }^{57}$ In seeking to align transactional courses to the ABA Standard of " $[\mathrm{k}]$ nowledge and understand of substantive and procedural law" by creating a learning outcome that "[s]tudents will be able to understand and distinguish provisions in corporate bylaws[,]" some faculty created a plan to accomplish that outcome and ensure the course was designed to do so starting from the teaching perspective. ${ }^{58}$ It was recognized that working backwards from the Standard to arrive at all the connections that should be made to accomplish this outcome was difficult. ${ }^{59}$ The approach taken was to start with the way many law faculty have taught their courses in the past - to make an outline of what it is they think they want to teach, think they should teach, or they have taught in the course in the past - forward planning, starting with teaching. However, it is important to think broadly in this planning - to include a lot of informal inputs-from others that teach the course in your school, and external guidelines that you have adopted (such as the National Conference of Bar Examiners outline if appropriate to a subject), a textbook's table of contents, and personal and professional knowledge of a subject from a practice point of view.

From there, the next step is to take the forward created outline and match it with the ABA Standard or other learning outcomes provided by the school-most of which cover substantive and procedural law, legal analysis and reasoning, legal research, problems solving, communication, and professional and ethical responsibilities. ${ }^{60}$ The key at this point is to see what is left from the outline of teaching that does not accomplish the goal of the ABA Standard or your learning outcome. Whatever is "leftover" from what you thought you would teach should have one of two things happen to it. First, one could expand their choice or creation of learning outcomes for that course to include the additional materials they planned to teach, or second, they can edit their teaching outline down to conform to your learning outcome, deciding that although topics they may have planned were interesting, they were just not directly relevant in this course. Either way, they have started with the ideas to teach, formulated outcomes, and then come around again to ensure alignment.

Once you have modules in your course that match up with your learning outcomes, you can finish the reverse planning process-lock in your learning outcomes and then once again revisit and refine that course outline. Are your teaching modules balanced among your outcomes as intended, or do three-quarters of the course hit one of four outcomes you've listed? Should

\footnotetext{
57 Judy Rosenbaum et al., Making the Grade: Assessment of Learning Outcomes in Transactional Skills Courses, 18 TENN. J. BUS. L. 593, 593-94 (2016).

58 Id. at 594.

59 Id.

${ }^{60}$ See Learning Outcomes Database,U. St. Thomas, https:/www.stthomas.edu/hollorancenter/ resourcesforlegaleducators/learningoutcomesdatabase/ (last visited Sept. 26, 2018).
} 
further adjustments be made? Once that balance has been achieved, the process of planning assessments specifically tailored to those aligned modules and outcomes can begin. The modified forward planning process - an offshoot of how faculty traditionally work - may bring great success for many reluctant adopters of learning outcomes, and truly assist in aligning courses with institutional needs.

Whether planning begins with backward planning, forward planning, or central planning, the process will help ensure that the curriculum process is a complete and useful one.

\section{B. Curriculum Mapping to Ensure Programmatic Learning Outcomes Are Met}

Law schools should be using curriculum mapping to ensure that there is coordination of what is being taught throughout school in different courses, throughout different sections of the same course, and that any overlap of skills and doctrine is intentional to enhance student learning both for law practice and the bar exam. ${ }^{61}$ Therefore, it is important that learning outcomes for each course, program, or degree should not be created in a vacuum. Before setting learning outcomes for any level, faculty should be consulting with each other, as well as judges and practicing attorneys to understand what new lawyers practicing in a wide variety of areas need. ${ }^{62}$ Without this type of coordination, learning outcomes cannot be the tool to maximize student achievement as intended.

Curriculum mapping can be accomplished a number of ways. Even if faculty is skeptical about curriculum mapping, an easy place to start is by listing each large-scale program learning outcome - and then under each, list each course. For example, one learning outcome of a degree could be "Research legal issues thoroughly and efficiently," one that Shepard Broad College of Law adopted as a program-wide learning outcome in $2016 .^{63}$

That learning outcome should be mapped to all courses in the curriculum which have adopted that learning outcome for the course, thus aligning it with the school's core purposes. Such a map might look like this:

\footnotetext{
61 Brent E. Newton, The Ninety-Five Theses: Systemic Reforms of American Legal Education and Licensure, 64 S.C. L. REV. 55, 87-88 (2012).

${ }^{62}$ Fisher, supra note 5, at 229-30.

63 J.D. Program: Program of Study, NOva SOUTHEASTERN UNIV., https://www.law.nova.edu/jdprogram/program-of-study.html (last visited Sept. 29, 2018).
} 


\begin{tabular}{|c|c|c|c|c|}
\hline \multicolumn{5}{|c|}{$\begin{array}{l}\text { Learning Outcome \#4: } \\
\text { Students completing this instructional offering are expected to: } \\
\text { Research legal issues thoroughly and efficiently. }\end{array}$} \\
\hline & $\begin{array}{l}\text { Required } \\
\text { Courses }\end{array}$ & $\begin{array}{l}\text { Elective } \\
\text { Courses }\end{array}$ & $\begin{array}{l}\text { Seminars } \\
\text { (Satisfy } \\
\text { Writing } \\
\text { Requirement) }\end{array}$ & $\begin{array}{l}\text { Experiential } \\
\text { Opportunities } \\
\text { (Workshops, } \\
\text { Clinics, Field } \\
\text { Placements) } \\
\text { Satisfy } \\
\text { Experiential } \\
\text { Learning } \\
\text { Requirement }\end{array}$ \\
\hline $\begin{array}{l}\text { FIRST } \\
\text { LEVEL } \\
\text { EXPOSURE: }\end{array}$ & $\begin{array}{l}\text { Legal } \\
\text { Research } \\
\text { and } \\
\text { Writing I } \\
\text { and II }\end{array}$ & & & \\
\hline $\begin{array}{l}\text { SECOND } \\
\text { LEVEL } \\
\text { EXPOSURE: }\end{array}$ & & $\begin{array}{l}\text { Advanced } \\
\text { Legal } \\
\text { Research } \\
\text { Techniques; } \\
\text { Conflicts of } \\
\text { Law; Criminal } \\
\text { Procedure; } \\
\text { Information } \\
\text { Privacy Law; } \\
\text { International } \\
\text { Protection of } \\
\text { Human } \\
\text { Rights; } \\
\text { Judicial } \\
\text { Opinion } \\
\text { Writing; } \\
\text { Juvenile Law; } \\
\text { Ocean and } \\
\text { Coastal Law; } \\
\text { Sports Law; } \\
\text { Trademark } \\
\text { Law \& Unfair } \\
\text { Competition; } \\
\text { Workers } \\
\text { Compensation. }\end{array}$ & $\begin{array}{l}\text { Animal Law; } \\
\text { Legislation } \\
\text { Seminar; Art } \\
\text { Law Seminar; } \\
\text { Bioethics } \\
\text { Seminar; } \\
\text { Caribbean } \\
\text { Law Seminar; } \\
\text { Civil Rights } \\
\text { Litigation } \\
\text { Seminar; } \\
\text { Comparative } \\
\text { Corporative } \\
\text { Governance } \\
\text { Seminar; } \\
\text { Comparative } \\
\text { Law Seminar; } \\
\text { Constitutional } \\
\text { Decision- } \\
\text { making } \\
\text { Seminar; } \\
\text { Elder Law } \\
\text { Seminar; } \\
\text { Environmental } \\
\text { Enforcement } \\
\text { Seminar; Law } \\
\text { and Medicine } \\
\text { Seminar; Law } \\
\text { Finance and } \\
\text { Markets } \\
\text { Seminar; }\end{array}$ & $\begin{array}{l}\text { Disability } \\
\text { Law; Drafting } \\
\text { and } \\
\text { Negotiating } \\
\text { Intellectual } \\
\text { Property; } \\
\text { Elements of } \\
\text { Legal } \\
\text { Analysis; } \\
\text { Family Law } \\
\text { Litigation } \\
\text { Workshop; } \\
\text { Will Drafting } \\
\text { Workshop. }\end{array}$ \\
\hline
\end{tabular}




\begin{tabular}{|c|c|c|}
\hline \multicolumn{3}{|c|}{$\begin{array}{l}\text { Learning Outcome \#4: } \\
\text { Students completing this instructional offering are expected to: } \\
\text { Research legal issues thoroughly and efficiently. }\end{array}$} \\
\hline & $\begin{array}{l}\text { Legislation } \\
\text { Seminar. }\end{array}$ & \\
\hline $\begin{array}{l}\text { THIRD } \\
\text { LEVEL/ } \\
\text { CAPSTONE } \\
\text { EXPOSURE: }\end{array}$ & & $\begin{array}{l}\text { AIDD Clinic; } \\
\text { Bankruptcy } \\
\text { Workshop; } \\
\text { Children and } \\
\text { Families } \\
\text { Clinic; } \\
\text { Consumer } \\
\text { Protection } \\
\text { Internship. }\end{array}$ \\
\hline
\end{tabular}

This map is a tool that informs the faculty and students of how they will meet this outcome through the program, a necessary part of demonstrating that it is met. The second step after mapping involves conversations by groups of faculty members. This big picture discussionamong faculty teaching all of these courses-ensures that their individual courses each meet the common stated learning outcome, as well as ensures that the exposure students receive is categorized in the proper way-as second level or capstone. A faculty consensus about what it means to have a course designed to meet outcomes is essential to actually planning a program of legal education that is outcome based.

One fear expressed is that on the course level, learning outcomes driving syllabus design will force the teaching to be solely "teaching to the test."64 That criticism is short sighted. Regardless of the method of curriculum designed employed, the focus is-and always should be the ultimate question-what do I want students to be able to do or know after this course? Every course should have a map. Many professors use a textbook to guide them as to what their coverage should be, while others may use examples of syllabi they have seen from other professors, or simply pick and choose topics in a subject that they prefer, or without any documented reason, deemed "important." Learning outcomes can change that. A map should indicate "where students first encounter the outcome, where students practice the outcome, and at what point the students can be expected to ... achieve the outcome."65 Using these tools helps courses stay on track - as to the outcome-without being about the test itself. It has been well documented that good teaching can involve setting clear goals and assessments, without

\footnotetext{
64 Lynch, supra note 33, at 998.

65 Fisher, supra note 5, at 232.
} 
changing the method of your teaching to accomplish those goals. ${ }^{66}$ Regardless of the order the course is set up, the focus isn't the assessmentit is the outcome.

Therefore, this coordination among faculty, discussed more in the next section, is one of the key tools to successfully mapping a curriculum to improve student learning-ensuring courses, programs, and degrees are aligned so that student learning can properly be measured.

\section{Cooperation Among Sections of Same Course and Vertically Through Curriculum}

One of the most explosive topics among law faculty is the concept of academic freedom. ${ }^{67}$ This has been raised two ways within the concepts of learning outcomes and accountability for student learning. ${ }^{68}$ First, some professors have indicated just the idea of being required to "articulate, identify, and assess outcomes" as an impingement on academic freedom. ${ }^{69}$ While genuine attacks on academic freedom should be taken seriously, ${ }^{70}$ the discussion of what students should learn in a class and the ability to measure what is learned is in no way inconsistent with content-based academic freedom. ${ }^{71}$ There is no censoring of ideas, knowledge, nor judgment restricted by the concept of stating the faculty member's intended outcome of a course, nor being required to measure whether students achieved the outcome picked by the faculty member.

The second issue that may arise is that the history of law courses has been one of "considerable freedom" to operate a course individually, not only to subject matter within a year, but within various sections of that same course. $^{72}$ Professors were not required to disclose objectives or the methodology for meeting them, furthering this attitude. ${ }^{73}$

It has been asserted that with the implementation of the ABA Standard, placing an obligation on institutions, the ownership of learning outcomes-previously considered to be part of the domain of a particular professor who "owns" a course - is now a collective standard shared by the institution. ${ }^{74}$ Thus, the process of having groups of faculty teaching multiple

\footnotetext{
66 Lynch, supra note 33, at 1000.

${ }^{67}$ See generally William H. Daughtrey Jr., The Legal Nature of Academic Freedom in United States Colleges and Universities, 25 U. Rich. L. Rev. 233 (1991).

68 Lynch, supra 33 at 990

69 Lynch, supra 33 at 990.

${ }^{70}$ See generally John M. Elmore, Institutional Attacks on Academic Freedom: The Impact of Mandates by State Departments of Education and National Accreditation Agencies on Academic Freedom, 1 AAUP J. ACAD. FREEDOM (2010), available at https://www.aaup.org/sites/default/files/Elmore.pdf.

71 Lynch, supra note 33, at 993.

72 Steven 1. Friedland, Contemporary Issues in Outcomes-Based Education: Outcomes and the Ownership Conception of Law School Courses, 38 WM. MiTCHELL L. REv. 947, 957 (2012).

${ }^{73} \mathrm{Id}$. at 958 .

${ }^{74} \mathrm{Id}$. at 951 .
} 
sections of the same course-which have selected the same learning outcomes-to meet and ensure that their courses, collectively, have a core overlap of substance and skills. Therefore, they are all meeting the learning outcome which they have collectively designated, all while being held accountable by their institutions and maintaining their own academic freedom.

The academic freedom argument - that a professor may fully control the content of their course unbridled, is clearly misguided. Institutions have responsibilities to students to deliver a core promised curriculum. This core curriculum can be defined by learning outcomes, and each faculty member should be accountable for delivering that content.

Academic freedom has been commonly understood to be the "ability of a teacher to express ideas, particularly within classrooms and scholarship contexts, and explore a subject without institutional limitation or interference. $^{.775}$ A law school has a responsibility to ensure that its core education reaches its students in ways that are responsible to students. It is * well established that a school, program, or department can have some control over what a course will cover. ${ }^{76}$ Given the lockstep nature of what we require from $1 \mathrm{~L}$ students, it makes sense that there needs to be some institutional definition of what that $1 \mathrm{~L}$ curriculum entails. If we require all students to take Torts, there must be some core identity of what is covered, and what the outcome of a Torts class is - otherwise, why bother having the requirement reach all students? The course itself was presumably approved by the institution to be offered for a reason-as such, institutional alignment is important.

Ideally, the process for using learning outcomes to best ensure that a program of legal education sets consistent outcomes for students across multiple sections of the same course. For example, "Torts" at its core would be the same experience for all students regardless of which teacher they were assigned. To ensure that the course is properly inserted into a curriculum with a purpose that is measured it is best to have the faculty themselves meet in small "departmental groups" to determine the alignment. These groups should be both horizontal-across multiple sections of the same course-and vertical-among multiple courses designed to take in sequence that serve as foundations or advanced versions to ensure alignment in that way.

The impression is that this type of control can be a slippery slope towards improper impingement on academic freedom, but that concern is unfounded. Learning outcomes do not impact academic freedom, regardless

${ }^{75}$ Id. at 964

76 Lynch, supra note 33 at 994; NATIONAL RESEARCH COUNCIL, ET AL., KNOWING WHAT STUDENTS KNOW: THE SCIENCE AND DESIGN OF EDUCATIONAL ASSESSMENT 224 (2001) (ebook). 
of how it is defined. ${ }^{77}$ Rather than administratively dictating what that core identity of a course should include, the faculty members teaching multiple sections of that course should agree on the concepts, using objective measures which they want students to achieve, to justify why it is part of the curriculum. For example, if institutionally, a school requires Torts because that subject is tested on the bar exam, then the outline of what is tested on the bar exam should help drive that conversation of what the core identity of the course is. If learning practice-ready skills from an upper-class course which relies on Torts for a foundation is a driving reason to require Torts in the curriculum, then those foundational building blocks preparing students for that further learning should be part of that conversation as well. In this way, faculty are working together to identify and ensure a core curriculum is delivered both across sections in the same course, and vertically through subjects that students will encounter sequentially in the curriculum.

To have a truly integrated curriculum, the individual silos of doctrine in the first year, skills in the second year, and live client in the third year must be stripped of their independency, and be integrated. ${ }^{78}$ Additionally, the curriculum must be properly sequenced, through considering assignments, skills, competency, and programs. ${ }^{79}$ Consensus should be reached among faculty in the curriculum as to both substance and sequence. ${ }^{80}$ Having the entire faculty invested in learning outcomes can improve and facilitate learning across the curriculum. ${ }^{81}$

This process can have learning outcomes and their related assessments enhancing the program of legal education in multiple ways to improve student learning rather than being a divisive concept. First, plan the curriculum to ensure consistency, rather than allowing it to grow organically as personnel change in the teaching group and new textbooks are released. When faculty collaborate to plan the core of what they are teaching in a course - including documenting what the purpose of the course is, ensuring its alignment with other sections of that course, other courses, with their own and external assessments (such as the bar exam), and with the learning outcomes of the program of legal education as a whole - the use of learning outcomes is at its most productive.

An additional benefit to communicating to students what curriculum they will be taught, regardless of the professor teaching it, is ensuring that progress is made for all students on the path the institution has chosen, toward further learning, skills, and achievements. Rather than faculty merely "checking a box" that Torts "has learning outcomes," a program of legal

\footnotetext{
77 Friedland, supra note 72 , at 964.

78 Adam Lamparello, The Integrated Law School Curriculum, 8 ELON L. REV. 407, 416-17 (2016).

79 Id.

80 VanZandt, supra note 14, at 332.

81 Id.
} 
education should confirm the purpose of the course, the accomplishment of the course, the sequencing of the course within the program, and that the assessments truly do test that progress. All law schools have these responsibilities to students, and this is a clear plan to accomplish that goal.

\section{Tying Course Evaluations to Learning Outcomes to Measure Gains}

One obstacle that can arise when learning outcomes and syllabi are aligned, is the fear by many faculty members of representing that they will accomplish a certain goal, and then being judged unfairly on the students' ability to having met that goal. ${ }^{82}$ However, it is important to note that unlike school districts that base teacher bonuses on students' standardized test scores, ${ }^{83}$ the purpose of this measurement in legal education is to improve curriculum and student learning, not to find a backhanded way to find out if professors are good teachers. Measuring the meeting of learning outcomes by students themselves is not equivalent to an evaluation of faculty tied to assessment results, which should not happen. ${ }^{84}$ Schools must communicate this intent clearly to faculty to assist with this concept. One plan to accomplish this goal is to reinvent course evaluations to measure student learning rather than faculty "performance."

Getting feedback from students that they do not perceive they have met a learning outcome stated for a course and that changes to a course or instructional method may be needed is very different than judging a professor's work for promotion or retention based on that information. Instead, it is a refocusing of the questions asked and information gathered from students, away from traditional evaluation questions, which themselves have often been criticized as being rife with implicit bias. ${ }^{86}$

Clinical and field placement programs have adopted the understanding of this for years. ${ }^{87}$ Students participating in outside placements doing legal work have been asked to assess their sites for accomplishment of the learning outcomes, such as acquired skills, and their development as a lawyer. ${ }^{88}$ Such evaluations can get specific information regarding the

82 Lynch, supra note 33, at 999-1000.

${ }^{83}$ Leslie Postal, Florida Gets New School Rules on Testing, Books, Bomuses, ORLANDo SENTINEL (July 8, 2017, 7:00 AM), http://www.orlandosentinel.com/features/education/school-zone/os-floridaschool-laws-new-20170706-story.html.

84 Roberts, supra note 12, at 469.

${ }^{85}$ Eva Lilienfeld, How Student Evaluations Are Skewed against Women and Minority Professors, The Century Found. (June 10, 2016), https://tef.org/content/commentary/student-evaluations-skewed-womenminority-professors/.

${ }_{86}$ Eva Lilienfeld, How Student Evaluations Are Skewed against Women and Minority Professors, THE CENTURY FOUNDATION (June 10, 2016), https://tcf.org/content/commentary/student-evaluations-skewedwomen-minority-professors/.

${ }^{87}$ Ann Marie Cavazos, The Journey Toward Excellence in Clinical Legal Education: Developing, Utilizing and Evaluating Methodologies for Determining and Assessing the Effectiveness of Student Learning Outcomes, 40 Sw L. REV. 1, 39 (2010).

${ }^{88}$ Id. 
development of legal writing, research legal analysis, interviewing and counseling, advocacy skills, negotiation skills, and meeting deadlines by the student; all of which can be, and probably are, learning outcomes for such a placement. ${ }^{89}$ Additionally, this type of self-reflection-evaluating one's own learning - is another skill that, by itself, may be a learning outcome, because an aware, self-starter learner who is able to understand their progress toward goals is a successful professional.

The process is an easy one for schools to implement. The instrument given to students, in any format used, can easily be edited. Instead of asking such questions "overall rating of a professor" or whether the "professor communicated well with the class"-questions that focus on the teaching, rather than the learning, such as the following, can be substituted:

1. The course followed the topic coverage, and learning objectives provided in the syllabus.

2. The course materials were effective for the topic coverage and learning outcomes of the course.

3. The instructor provided useful feedback throughout the semester through discussions, quizzes, and midterms, and/or graded written assignments.

4. The instructor helped me develop my critical analysis of the topic coverage. ${ }^{90}$

Such questions flip the focus of the evaluation from teaching to learning, and thus are part of the useful assessment of whether learning outcomes are met.

In short, tying evaluations to learning outcomes are another method of ensuring that learning outcomes are met, and that they are a useful tool in curriculum planning.

\section{E. Expanding the Idea of What Outcomes Can be for Legal Education}

Altering compliance to align with these new ABA Standards, many schools may be tempted to stick with what they think they know, and already do, thereby setting traditional law school doctrine and skills as their learning outcomes. By limiting the outcomes for legal education to "legal doctrine," "legal research," or "legal analysis," schools are missing out on the opportunity to reshape legal education to provide students with the skills necessary to be practice ready in this new world. It is important to note that the ABA Standard itself includes "competence" as a proper outcome with regard to being a "competent and ethical participation as a member of the legal

\footnotetext{
89 Id.

90 See generally id.
} 
profession."91 In considering whether students are competent, schools must measure the achievement of this outcome, although "competency" is not defined. ${ }^{92}$ It is left up to the law schools to define what is included in competency, and therefore, schools should be thinking broader and deeper.

One path to consider is to craft learning outcomes to include learning processes themselves, not just the competencies of end products such as doctrine or practice skills. ${ }^{93}$ By including the process of understanding the skills learned, such as reasoning and analysis, as a goal for themselves, as well as measuring those processes in learning, teachers can pull back the curtain on the learning process for students. ${ }^{94}$ This will improve learning through their inclusion, and will set students up for further learning success in other settings. ${ }^{95}$

Self-regulated learning is one of the most important skills a student can attain. ${ }^{96}$ Creating a learning outcome to become a self-regulated learner not only sets a student up for the ability to learn in the future, but helps in developing self-efficacy, which assists a student in managing their knowledge as it is gained. ${ }^{97}$ Self-regulated learning is one of the first attributes that Best Practices of Legal Education urges students to develop. ${ }^{98}$ With the age of comprehensive law firm mentoring behind us, nearly 50 law schools have identified "self-directed learning" as a learning outcome for their students."

There is no question that the ability to take control of one's own learning is one of the most important things a law student can do to ensure future success. However, as a learning outcome that a school is setting, a difficult question remains how that skill is going to be measured. ${ }^{100}$ Schools will need to create new types of assessments, and possibly even new types of curricular structures in order to demonstrate that students are learning this skill. ${ }^{101}$ Many of the ways that traditional legal educations are set up, such as required first year courses with little autonomy, do not provide the structure for such learning nor the measurement of it. In fact, this set up may present obstacles to accomplishing this goal. ${ }^{102}$ However, as noted above, other areas

\footnotetext{
91 Wegner, supra note 38 , at 679.

92 Id. at 680 .

93 Anthony Niedwiecki, Teaching for Lifelong Learning: Improving The Metacognitive Skills Of Law Students Through More Effective Formative Assessment Techniques, 40 CAP. U. L. REV. 149, 166 (2012).

${ }_{94}$ Id.

95 ld. at $171-73$

* See Elizabeth M. Bloom, Teaching Law Students to Teach Themselves: Using Lessons from Educational Psychology to Shape Self-Regulated Learners, 59 WAYNE L. REV. 311, 312-13 (2013); Emily Grant, The Pink Tower Meets the Ivory Tower: Adapting Montessori Teaching Methods for Law School, 68 ARK. L. REV. 603, 605 (2015).

97 Bloom, supra note 96 , at 328 .

98 Stuckey, supra note 36 , at 263.

99 Jerome Organ, Legal Ed's Futures: No. 38, PrAwFS Blog (Mar. 28, 2018, 1:37 PM), http://prawfsblawg.blogs.com/prawfsblawg/2018/03/legal-eds-futures-no-38-jerome-organ.html.

${ }_{100}$ Id.

101 Id.

102 Id.
} 
of legal education may be an excellent fit for these more nontraditional outcomes. ${ }^{103}$

Self-efficacy is defined as a "person's belief in his or her capability to successfully perform a ... task[,]" through which a person can determine a level of effort and persistence in any given task is also difficult to assess. ${ }^{104}$ The ability for a student to understand what he or she can do with the skills they possess, intersects them with the perception of the task ahead, and assesses their progress in developing the skills necessary to develop to succeed in the practice of law. ${ }^{105}$ Again, curricular redesign may be necessary.

Self-regulated learners with self-efficacy possess necessary skills that many faculty members may assume are embedded into other concepts, such as time management, study strategies, and the ability to seek help. ${ }^{106}$ These traits lead to long-term success and should be the outcomes, not mere quietly understood tools used to gain other measures. More is needed to incorporate self-regulated learning and efficacy.

In looking at how to approach this skill of self-efficacy, and how to incorporate it into the law curriculum, more than one scholar has compared the Montessori school approach to instilling lifelong learning to teaching skills needed in law school and suggested ways the Montessori approach could be adapted to bring success for law student at achieving this outcome. ${ }^{107}$ In this analysis, Montessori's Three Elements of Education were featured; the learner, the trained adult, and the environment. ${ }^{108}$ The environment of law school has been compared to the unusual blend of rigidity and flexibility of the Montessori classroom, where students drive their own learning and making the lessons learned there relevant in thinking about teaching and learning in law school. ${ }^{109}$ While not every part of every law school class can have self-directed learning as an outcome, nor involve this kind of learning, ${ }^{110}$ all law school classes can work toward better self-discovery skills for students as part of the legal education outcome.

The most concrete comparison between the Montessori approach and the ABA approach of measuring learning outcomes and assessments, is how law schools are now charged with observing their students "attainment of

$103 \mathrm{Id}$

104 Jason S. Palmer, "The Millennials are Coming!": Improving Self-Efficacy in Law Students Through University Design in Learning, 63 CLEV. ST. L. REV. 675, 690 (2015).

105 Id.

106 Bloom, supra note 96 , at 334-37.

107 Grant, supra note 96. See generally Abigail Loftus DeBlasis, Building Legal Competencies: The Montessori Method as a Unifying Approach to Outcomes-Based Assessment in Law Schools, 42 OHIO N.U. L. REV. 1 (2015).

108 Grant, supra note 96, at 611.

109 Id. at 605.

$110 \mathrm{Id}$. at 640. 
stated learning outcomes and, to the extent those learning outcomes are not achieved, to diagnose the causes of those shortcomings and refine curriculum or teaching approaches accordingly." 111 Such practice is part of the development of the Montessori approach and a necessary part of that experience. $^{112}$

One key to developing these skills in the curriculum is to note that not all legal education skills need to be developed all at once, or right away. Dr. Montessori advocated that students had development periods called "sensitive periods," in which a student would be more advantaged in learning at a particular point in his or her development. ${ }^{113}$ Likewise, law students may have different periods where different skills or attributes that are part of a learning outcome may be riper for learning. ${ }^{14}$ For example, increasing selfdirected learning, cultural competency skills, and professional identity development in the third year when students are ready to apply what they have learned to launch their professional careers. ${ }^{115}$ Thus, the way to assess these skills is to use a curriculum map to plan where they are aligned with the curriculum, and work together to ensure the outcomes are met.

Last, the Montessori concept of "Cosmic Education"-where students pursue a topic of interest across disciplines - also has been advocated by some as an appropriate model for law student's education. ${ }^{116}$ The idea is that students interested in transactional law, for example, can best learn when the school integrates the necessary competency skills into a variety of doctrine courses and eliminates the silos separating doctrinal and experiential learning, which have existed in legal education for years.

Law School courses should be emphasizing "problem solving, risk management, and strategic thinking" to better train students for the profession. ${ }^{117}$ Those law schools with traditional learning outcomeslearning only doctrine and legal analysis generally measured by the bar exam-are being left behind in the race to best prepare students for practice.

Another learning outcome to measure competency student collaboration, because individualism is unduly stressed in law school compared to the real-world profession. ${ }^{118}$ The individual nature of student assessment and learning in law schools is nothing more than a mirror of how the faculty learned themselves. However, by making defined outcomes in collaboration and teamwork, these additional competencies can be learned to

111 DeBlasis, supra note 107 , at 27.

${ }_{112}$ Id.

113 Id. at 32.

114 Id.

115 Id. at 32-33.

116 Id at 35. See also Lamparello, supra note 78, at 417.

117 Newton, supra note 61 , at 84 .

118 Id. at 89. 
better align students' abilities with the needed professional skills. These outcomes seem particularly ripe for new experiential course experiences, tying the learning into the real-life type of situations in which they will occur for students.

The Humanizing Legal Education movement has achieved recognition by the creation of the Section on Balance in Legal Education of the American Association of Law Schools, which has three basic principles to improve legal education. ${ }^{119}$ First, law schools should create less stressful learning environments. ${ }^{120}$ Second, schools should adopt student-centered teaching. ${ }^{121}$ Third, law schools should incorporate more values education. ${ }^{122}$

All of these aspects should be considered by law schools in setting expanded learning outcomes to align with necessary skills.

Some law schools have begun the process of defining competency (and the accompanying outcomes) by distilling and further dissecting more traditional outcomes and competencies that law schools may already have. For example, in one school there was a course focused on written and oral communication skills for a law practice, and the school set outcomes for four types of professional writing, rather than just traditional legal writing. The four types of written communication are as follows: legal blogs, client newsletters, bar journal articles, and client advisories, as well as having outcomes for the oral skills to give a CLE to non-specialists and lay audiences. ${ }^{123}$ These outcomes are an offshoot of traditional writing and oral communication skills but refined further to best meet student learning needs for their practice.

One last potential to expand learning outcomes for legal education is to include an outcome of legal education as leadership. ${ }^{124}$ Schools have been embracing leadership in their curriculum, with more schools than ever having an elective course, and even one having a required course in such. ${ }^{125}$ Even law schools who have not expressly adopted leadership programs are adopting competencies through learning outcomes that lead to successful leadership training, such as self-knowledge and self-awareness. ${ }^{126}$ In short, leadership qualities are part of the way these schools are broadly defining competencies and setting their goals to meet them.

\footnotetext{
119 Fisher, supra note 5, at 246.

${ }_{120}$ Id.

121 Id.

$122 \mathrm{Id}$.

123 Mavrova Heinrich, supra note 25, at 112

124 See generally Neil W. Hamilton, Leadership of Self: Each Student Taking Ownership Over Continuous Professional Development/Self-Directed learning, U OF ST. ThOMAS (MINN) LEGAL STUDIES RESEARCH PAPER 18-09 1 (May 8, 2018), available at https://ssrn.com/abstract=3176084

125 Id.

126 Id. at 9.
} 


\section{F. Better use of Formative Assessments for Measurement of Competencies}

One of the keys to unlocking the potential of learning outcomes to improve student learning is for faculty to do a deeper dive into understanding formative assessments and how to use them to measure outcomes in a competency-based education. "[A] competency-based education model focuses on what the learners can demonstrate and do[,]" with the competencies being defined by these outcomes. ${ }^{127}$ Thus, the assessment criteria measuring these competencies are based on this demonstration of the various competencies-and not necessarily on merely the acquisition of knowledge facilitated by the teacher. ${ }^{128}$ Instead, the focus is on the application of knowledge as driven by the learner. ${ }^{129}$ Therefore, law schools need to readjust their perspectives on the types of assessments used to measure their outcomes.

It is somewhat of a startling concept to realize that "[o]ur students do not learn what we teach."130 If this were true, a listing of what was taught to students would be an accurate list of what students learned, without any need for assessment. ${ }^{131}$ Unfortunately, many of those in legal education anecdotally can confirm that for many years, creating these lists of what we taught, and assuming all items were accomplished, is how many law schools have operated. But the concept of teaching and learning being two sides of the same coin is one that is deep in educational theory that spans across many cultures. ${ }^{132}$ You cannot separate the reciprocity between teacher and learner, which improves both teaching and learning, but are not automatically equivalent. 133 Teachers must remember that "learning cannot be mandated; [that] teachers cannot guarantee that any particular student will learn" any particular amount of material, regardless of the teaching that may have occurred. ${ }^{134}$ As a result, from the beginning, law schools need to take a better look at assessments to understand both what they are, how to use them, and why to use them, and to measure actual learning, not just perceived learning.

Although we use the word "assessment" frequently in law school today, few faculty members have given deep thought as to what it really means, with most immediately associating the word with quizzes or tests as they may already exist in their courses. However, assessments are broader in scope, and can be defined as "the systematic collection, review, and use of

127 Id. at 2 .

128 Id.

129 Id. at 3 .

130 Dylan Wiliam, Assessment: The Bridge Between Teaching and Learning, 21VOICES FROM THE MIDDLE 15 (2013), available at http://www.ncte.org/library/NCTEFiles/Resources/Journals/VM/0212dec2013/VM0212Assessment.pdf.

131 Id.

132 Relationship Between Teaching and Learning, SMARTPRIMARYED, https://smartprimaryed.com/ the-relationships-between-teaching-and-learning/ (last visited Sept. 29, 2018).

$133 \mathrm{Id}$.

134 Wilson \& Peterson supra note 4, at 9. 
information about educational programs undertaken for the purpose of improving student learning and development." ${ }^{.135}$ The key to this definition is that any instruments used to measure learning are not isolated tools-they are part of a programmatic purpose - and centered around student learning for the purpose of learning. They should not be used just to give grades.

It has been asserted that "[a]ssessment methods and requirements have a greater influence on how and what students learn than any other single factor." 136 It is easy to lose sight of the fact that the "central purpose of assessment is to discover whether students are achieving the learning outcomes set for a particular skillset, an individual course, or an entire instructional program."137 For many teaching at a law school, and for many students, assessments equal grades. In short, law faculty must adjust to the fact that grading is not the same as assessing learning outcomes. ${ }^{138}$

Instead, law schools should be concentrating on their systematic improvement of formative assessments to increase student learning. Formative assessments are "most effective" when they help clarify what is good performance, deliver high quality information, help to close the gap between current student performance and desired student performance, encourage - and enable - dialogue between the student and the faculty member, facilitate self-assessment, provide meaningful feedback to the faculty member, and encourage positive motivation. ${ }^{139}$ There are five stages of expertise that need to be developed for any outcome; novice, advanced beginner, competent, proficient, and expert. ${ }^{140}$ Formative assessments help students develop through these stages at their own pace within the set time. ${ }^{141}$ In setting learning outcomes, concentrating on a stage of development and measuring each stage can have a great impact on ensuring proper student learning.

There is no question that effective pedagogy involves formative feedback that provides both students and faculty the opportunity to gauge their progress as they move through both doctrinal content and skills toward an end of goal. ${ }^{142}$ This article would not be the first to encourage the use of formative assessments and to tout their benefits. However, there are scholars who indicate that many educators misuse the word "formative" in this context. $^{143}$ These scholars believe the word "formative" is not used to

\footnotetext{
135 Fisher, supra note 5, at 227.

136 Rogelio A. Lasso, Is our Students Learning? Using Assessments to Measure and Improve Law School Learning and Performance, 15 BARRY L. REV. 73, 76 (2010).

137 Mavrova Heinrich, supra note 25, at 108.

138 Roberts, supra note 12 , at 459.

139 Niedwiecki, supra note 11 , at 268.

140 Lasso, supra note 136 , at 89.

141 Id.

142 Daniel Schwarcz \& Dion Farganis, The Impact of Individualized Feedback on Law Student Performance, 67 J. LEGAL EDUC. 139, 140 (2017).

143 Wiliam, supra note 130 .
} 
describe the assessment itself, but "the function that the evidence generated by the assessment actually serves[,]" placing the emphasis on the learning process, not the instrument itself. ${ }^{144}$ Thus, any assessment can be used formatively, but this requires investment of time and energy by law faculty. ${ }^{145}$

One suggestion to kick-start the process of having assessments used formatively to improve student learning through is to "develop a culture of assessment in schools." 146 Therefore, schools must involve faculty and educate them about formative assessments. ${ }^{147}$

Good formative feedback from assessments is prompt, covers both the strengths and weaknesses of the students, and allows students and teachers to focus their efforts. ${ }^{148}$ Good formative assessments also enhances student learning. ${ }^{149}$ An empirical study at the University Minnesota confirmed this conclusion by determining that "among ... eight double sections at Minnesota between fall 2011 and fall 2015 in which one section received individualized feedback in one of its classes before the double-section final exam and ... [one] did not, the students from the section receiving [individual] feedback outperformed the students from the section that did not in every single class." 150 Such results were not discussing improvement in performance in the class where students received the feedback directly. ${ }^{151}$ Rather, the results indicated that when a student received feedback in their first year doctrinal class, the "students" exam scores improved throughout their course work within the first year of curriculum." 152 But in law school, assessments, even when added to the curriculum to comply with ABA Standards and to measure learning outcomes, still function "less as a means for measuring student learning than as a means for sorting and ranking students." 153 In other words, the assessments were only used for grading purposes. This focus needs to change institutionally through a culture change.

Within the assessments planned for a course, students must take a level of responsibility for meeting the learning outcomes as well. ${ }^{154}$ But in order to set students up to properly do this, teachers need to let students know what the learning outcomes are, so that they can take ownership of them. While a seemingly obvious concept, it would represent a relatively new

\footnotetext{
144 Id.

145 Id. at 17.

146 Benjamin Madison, Assessment of Program Learning Outcomes: Law schools Move into the Twenty-First Century, ALBANY L. BLOG (May 18, 2018), hitp://bestpracticeslegaed albanylawblogs.org/ 2018/05/18/assessment-of-program-learning-outcomes-law-schools-move-into-the-twenty-first-century/.

$147 \mathrm{Id}$.

148 Schwarcz \& Farganis, supra note 142 , at 140-41

149 Hess, supra note 43, at 86.

150 Schwarcz \& Farganis, supra note 142, at 142.

151 Id.

152 Id. at 143.

153 Lasso, supra note 136, at 82.

154 Hill, supra note 3, at 452.
} 
approach in a law school classroom because the atmosphere in the classroom has often been described as "hide the ball."155

Once students understand what the learning outcomes are for a particular class, formative assessments can be a positive way to increase learning with a low-stake impact on a students' portfolio. ${ }^{156}$ It is important to note that for many assessments, performance can impact who can continue their studies to completion and become eligible to sit for licensure, so having feedback solely for the purpose of learning is important. ${ }^{157}$

Another factor in using formative assessment is considering that in recent years, we have become more aware of the issues of mental health and wellness in the legal profession. ${ }^{158}$ As there is a negative relationship between "high-stakes" testing and student mental health, we should be more aware of this connection when considering the assessments used throughout a semester. ${ }^{159}$ While this is not to say that "high-stakes" testing should not be used and that grades should not count, the exposure to formative assessments, which would include feedback on student learning, can help ameliorate the impact of that stressful situation. This reality will lead to more accurate results overall - ones not skewed by well-being issues - which would also be summative as intended, and truly measure learning at that time.

By getting students to take responsibility for their learning, there are concerns about how low-stakes formative assessments will be viewed by students. ${ }^{160}$ The concern is that students will not take these assignments seriously, given the competitive nature of law students seeking points. ${ }^{161}$ However, through proper communication and the adjustment of faculty attitudes toward understanding the roles of these assessments in student learning, these hurdles can be overcome.

Further, formative assessments can help measure learning outcomes by allowing students to practice skills to accomplish a specific learning outcome. The importance of repetition and feedback has been well established over many years, yet that is still not the assessment process used by law schools. ${ }^{162}$ Learning theory dictates that students will have the most success at learning if "they are permitted and encouraged to do those things

\footnotetext{
155 Wiliam, supra note 130 , at 16.

156 Olympia Duhart, It's Not for a Grade: The Rewards and Risk of Low-Risk Assessment in the HighStakes Law Classroom, 7 ElON L. REV. 491, 493 (2015).

157 Hess, supra note 43 , at 86.

158 Dori Foster-Morales, Mental Health and Wellness: Destigmatizing the Discussion and Promoting Solutions, 92 FLA. BAR J. 1, 8 (Jan. 2018), https://www.floridabar.org/news/tfb-joumal/?durl=\%2Fdivcom \%2Fjn\%2Fjnjournal01.nsf\%2F8c9f13012b96736985256aa900624829\%2Fb l d6 la9bda5445 le852581 fd0 $06 \mathrm{cf} 4 \mathrm{e} 7$.

159 Duhart, supra note 156 , at 502.

160 Id.

161 Id. at 504-07.

162 Ramy, supra note 56 , at 837.
} 
over and over in many contexts."163 For many years, that practice in law school classrooms was limited to classroom recitation, private notetaking and briefing, and student repetition on their own outside of class. ${ }^{164}$ It is time that repetition was incorporated into the learning environment in a more structured way. By having students repeat and reinforce the doctrine and skills of the course in a structured setting, students will stay on track with the learning outcomes and they will meet the learning goals.

One reason this systemization of formative feedback is so important, is that effective learning requires effective feedback-the practice on its own will not lead to improved skills. ${ }^{165}$ Effective formative feedback should have four traits - it should be specific, positive, corrective, and timely. ${ }^{166}$

For students to meet learning outcomes, faculty must engage in an entire feedback loop. The ideal feedback loop has multiple steps:

- Set course goals and learning objectives;

- Create targeted assessments that indicate the extent to which students are achieving the course goals and learning objectives;

- Use assessment results to determine whether additional instruction in certain areas is required before moving on to new topics ...;

- Provide students with feedback so that they better understand their strengths and weaknesses and can adjust their study habits accordingly; and

- Move to a new topic. ${ }^{167}$

The "feedback loop" is daunting to many law professors, given the difficulty in time and effort needed. ${ }^{168}$ Feedback can be given in ways that is less time consuming, including multiple-choice questions, group feedback, grading rubrics that give the explanations to students, self-scored assessments, and peer scoring. ${ }^{169}$ Some shared examples of low time investment assessments that have big impact in the classroom include the minute paper, focusing on only the muddiest point, filling in the empty or partial outline, and using the single-issue hypothetical. ${ }^{170}$

163 See generally American Association for the Advancement of Science, Science for All Americans ch. 13 (1990) (ebook).

164 Id.

165 Id.

166 Hess, supra note 43, at 90.

167 Ramy, supra note 56, at 852.

$168 \mathrm{Id}$. at 854 .

169 Id. at 854-62.

170 Id. at 873-79. 
The effective feedback indicated above is often best accomplished with rubrics. Rubrics are intimidating to many faculty members, although they are a common and recommended way to give the formative feedback that students need. ${ }^{171}$ Many law faculty balk at them, and they unnecessarily try to reinvent the wheel-as if they just discovered the concept-and work to create them from scratch without any help. However, working in isolation is unnecessarily frustrating. Many scholars have shared their ideas of what can and should be in rubrics for grading and how to manage them, and law faculty must learn to work with others to come up to speed on the concept of effective feedback. ${ }^{172}$ In addition to working with others who have paved this path before them, collaboration with other faculty in the same subjects trying to navigate this path can help clarify those thoughts, encourage faculty in their use, and produce efficient rubrics to measure learning.

One challenge law faculty may face in adapting to rubrics to ensure student learning is clarifying when and which parts of the rubric are appropriate to share, and at what time. ${ }^{173}$ Sharing rubrics can be akin to sharing outcomes - having students understand what is expected of them can help enhance their ability to meet the outcome, and for many a complete change in the culture of the law school experience. There may be parts of a rubric appropriate to share before the assessment, such as general evaluation criteria (but not substance). After the assessment, additional information, including substance, skills, and style, is more explicitly laid out in connection with the feedback. ${ }^{174}$ The level of rubric used and shared may depend on whether these assessments have grades and how those grades are structured into the final course grade. ${ }^{175}$

Formative assessments are one of the most effective tools available to ensure that creative and meaningful learning outcomes are met. However, both institutions and faculty must make the necessary culture, structure, and curricular changes to accomplish this goal.

\section{G. Use of the Bar Exam to Appropriately Measure Learning Outcomes}

There is no question that nationwide, bar examination pass rates are on the decline, and that law schools are looking for ways to adjust their program of legal education to better these results. ${ }^{176}$ Having more students pass the bar exam is obviously an appropriate outcome of legal education, as after all, professional licensing is the goal of most students coming through

\footnotetext{
171 Rosenbaum et al., supra note 57 , at 598.

172 Id. at 598. See generally Cercone \& Lamparello, supra note 48, at 55-60.

173 Rosenbaum et al., supra note 57, at 603.

174 Id. at 603-04.

175 Id. at 604.

176 Louis N. Schulze, Jr., Using Science to Build Better Learners: One School's Successful Efforts to Raise Its Bar Passage Rates in an Era of Decline, FIU LEGAL STUDIES RESEARCH PAPER SERIES, Research Paper 17-11 1 (Apr. 2017), available at https://papers.ssm.com/sol3/papers.cfm?abstract_id=2960192.
} 
the program. The question though, is how to consider, and what to do with the information gained from the bar exam assessment, and how to consider it in the planning of a program of legal education.

Current external incentives often encourage law schools to organize their program of education to align heavily with the bar exam. ${ }^{177}$ These incentives include ABA Standards, admissions marketing, and of course, publicly published and widely disseminated first-time bar passage rates included in such highly publicized surveys such as U.S News and World Reports, despite the fact that many consider these metrics fundamentally flawed. ${ }^{178}$

Although heavily emphasis is placed on bar exam preparation, the bar exam fails to meaningfully assess the basic competencies required to be an entry-level attorney. ${ }^{179}$ While the bar exam may test legal doctrine, analytical ability, and writing, it fails to test oral communication skills, client skills, quantitative knowledge, financial literacy, and practical skills regarding litigation, transactional work, negotiations, or alternative dispute resolution. ${ }^{180}$ The bar exam should not be used as a total assessment of a school's learning outcomes, as it cannot truly take into account all the proper outcomes of a course, program, or degree. ${ }^{181}$ While this emphasis on doctrine is part of the picture, it is not an accurate report of the overall effectiveness of what a student has learned, nor should it be. ${ }^{182}$ Law school is and should be about far more than doctrine, legal writing, and analysis. Planning a curriculum that provides for anything less is doing students a disservice in preparing them for the practice of law. Therefore, faculty must put the bar exam in its proper place when revamping or making a curriculum and deciding how those outcomes will be measured.

Even when a bar exam is an appropriate assessment for certain learning outcomes of a legal education program, bar exams, as summative assessments, can only assess one stage of that development and provide little feedback when assessing other stages. Good assessments provide feedback and one must consider what feedback is gained from the bar exam, and how that can be used to ensure students meet the appropriate learning outcomes. ${ }^{183}$ A helpful way of thinking about the feedback from this assessment is that rather than it giving appropriate feedback to students - the assessment can only really provide successful feedback to the institution for appropriate

177 Jeremey Potter, Legal Education and Moneyball: The Art of Winning the Assessment Game, 11 CONN. PUB. INT. L.J. 327, 343 (2012).

178 Newton, supra note 61 , at 77.

179 Id. at 133

$180 \mathrm{Id}$.

181 Roberts, supra note 12, at 459.

182 Id. at 461.

${ }^{183}$ Lasso, supra note 136, at 92. 
adjustments to it in its curricular planning.

One approach to the bar exam as a summative assessment for program of education learning outcomes is to consider bar preparation itself - the process of preparing - about more than learning doctrine, even if the test itself may not be much more than that. One law school, with good success on the bar passage rates, considers that bar passage success due not to the culmination of what the school has done for its students doctrinally, but rather, students' ability to change the way they learn, and thus be better prepared for that doctrine based exam. ${ }^{184}$ Rather than relegating the preparation by students to the subjects tested, the school created bar preparation programs that met other learning outcomes for legal educationsuch as self-directed learning - and built success in all areas undertaken by students. ${ }^{185}$ In other words, a successful strategy for improving student learning is to create a curriculum that broadly develops students as learnersand enhanced doctrinal learning will follow.

A second approach is to take an aspect of the bar exam that has been criticized, and while preparing students for the exam, use that training to help meet the learning outcomes. A heavy criticism of bar exams has been the heavy reliance on multiple choice questions - after all, how many clients ask multiple choice questions? ${ }^{186}$ However, in the classroom, effectively designed multiple choice questions can be effective assessments to measure learning, by providing multiple, quick opportunities for feedback to students to encourage students to understand and gauge their levels of understanding in a wide variety of skills and doctrine, and providing reliable feedback to the teacher about the progress of students. ${ }^{187}$ Therefore, in preparing students for the bar exam, legal education programs can develop many formative assessments that can be widely used to increase all learning. As a result, the program of legal education can make lemonade from lemons in ensuring not only that students master the doctrine in order to take these multiple-choice assessments, and not only that students learn how to take multiple choice questions to prepare themselves to demonstrate that knowledge on the bar exam, but also that students have a reliable formative assessment to learn more about their learning progress throughout their education. ${ }^{188}$ Therefore, rather than programs of legal education being hijacked by a summative assessment that may not align with their creative learning outcomes, schools can instead leverage it to increase learning for all its outcomes.

184 Schulze, Jr., supra note 176.

185 Id.

186 Sophie M. Sparrow, Using Individual and Group Multiple-Choice Quizzes to Deepen Students' Learning, 3 ELON L. REV. I, 1 (2011)

187 Id. at 3.

188 Id. at 6. 


\section{H. Properly Leverage Data on Assessments Through Collection and Analysis}

It has been asserted that legal education is "woefully deficient" in using data to measure itself. ${ }^{189}$ Despite the critics who may claim that the legal education progress and purposes may not be measurable, others have been more optimistic. One scholar has compared legal education's challenge of measuring performance to that in the book Moneyball, which documented how a major league baseball team changed the way they evaluated talent by applying new ways of measuring, evaluating and drafting future players, to show that data can measure anything. ${ }^{190}$

The key to obtaining data that is useful to measure a program of legal education is the completion of the assessment cycle. ${ }^{191}$ This process has been described above as part of the concept of reverse planning, but here, the key emphasis falls on the final steps. After setting learning outcomes and aligning the teaching and assessments to them, the focus must be not only on measuring whether students achieved the outcomes and interpreting the data on those students from those assessments, but also on actually using the results to improve student learning. ${ }^{192}$ While some view the process as a linear one which may be "completed" by faculty, it is in fact truly a circular one, of evaluating and adjusting a program constantly based on this feedback loop to maximize student learning. ${ }^{193}$ The goal of the process is not to accomplish any individual step, but to reach the best plan for students, which will require constantly viewing, analyzing, and interpreting data. The cycle should never be finished, but constantly in motion.

However, schools must be cautious not to collect data simply for the sake of collecting it, but rather to ask the right questions in data collection and to use it. ${ }^{194}$ Data collected must give us more than the number of students who failed to meet certain benchmarks, but instead it should give us information in a specific and timely fashion as to what wasn't met to ensure programs of legal education can make adjustments in the teaching to improve student learning. ${ }^{195}$ Merely documenting failed teaching and learning without a path to correct it is a useless exercise - even though many faculty may view it as complying with the standard, and thus meeting their responsibilities.

However, law faculty are not conditioned to using data to adjust their teaching. First, there is often the personal belief by faculty that if students are not succeeding in their learning, then the students need to change, not the

\footnotetext{
189 Potter, supra note 177 , at 327.

$190 \mathrm{Jd}$. at 331.

191 Hill, supra note 3 , at 477.

192 Id.

193 Id. at 478.

194 Wiliam, supra note 130 , at 16-17

$195 \mathrm{Id}$. at 17.
} 
teaching. Second, even if faculty admit that teaching should be adjusted, it is not uncommon for teachers to operate according to their personal theories about what changes will work for their students. ${ }^{196}$ But when there is the opportunity instead to use data driven information to guide those theories, teachers are actually empowered to make real changes in their teaching to improve student learning. ${ }^{197}$ They have to buy in to using the data in ways that pave the road for change.

The first step in ensuring that faulty use the information is to obtain reliable and valid data, by using effective assessments. To be an effective assessment, it must reliably measure what it purports to be measuring. ${ }^{198}$ It may seem like an obvious concept-that reliability is effectuated if it is consistently demonstrable-that those who score well on an assessment, do so because they have the necessary skills and knowledge that the assessment purports to test. ${ }^{199}$ However, if the test purports to measure specific knowledge of a doctrine as applied to a hypothetical situation, but a student's grade is heavily dependent on their spelling, writing style, or knowledge from outside the subject (such as cultural competency), then the student's grade on the assessment does not adequately reflect their true understanding of the skills and knowledge the assessment sought to test-doctrine and analysis. Therefore, data gleaned from a students' performance on such assessments is not helpful to understand their progress on those two learning outcomes. In other words, the grade doesn't measure the students' true skills and knowledge, and the data will not be helpful.

A second potential problem in using assessments to gather data is that even if a faculty member has a reliable, properly aligned assessment, there must be a large enough sample to review and the faculty must consistently score the assessment to ensure its validity. ${ }^{200}$ Legal education can run into data issues because of validity issues, such as subjective evaluation of assessments and curved grading based on other students performance, rather than as against outcomes met, making the evaluation meaningless as to the students' meeting of learning outcomes. ${ }^{201}$ Making adjustments in courses to ensure student learning meets certain outcomes cannot, and should not, be based on one semester of tests graded by one person, and compared against another's performance, without any type of objective benchmark by which that data set is being measured. It is important to note that reliability and validity can operate independently of each other, and faculty must evaluate their own data for both. After all, if your car's speedometer is always registering at ten miles per hour too fast, it is reliable, but not valid, and you

\footnotetext{
196 Wilson \& Peterson, supra note 4 , at 14.

197 Id.

198 Hess, supra note 43 , at 88.

$199 \mathrm{Id}$.

$200 \mathrm{Id}$.

201 Id. at 88-89.
} 
would need to know that in understanding the information that it gives you.

For many faculty, the solution to ensuring both validity and reliability is to adopt rubrics. Faculty members who do not use rubrics - or any prethought objective measures against which a grade can be compared-are not setting themselves up to collect data on whether students are meeting learning outcomes. A test "looking like a B" is not a useful metric to begin with, even taking into account that your time spent grading can alter your view of what "looks" like a B, depending on how many exams you've graded and what else is going on around you as you do so. Much like one cannot "feel" if they are speeding, and that "feel" may change whether you've been driving a long time or not, grading without a guide cannot be reliable and valid.

Even when faculty use somewhat more tangible criteria and assign grades based on a standardized curve - this test is only a " $\mathrm{B}$ " because the one before it is an " $\mathrm{A}$ " and the one after it is a " $\mathrm{C}$ "- - faculty are depriving themselves of collecting useful data. The fact that one student did better or worse than another cannot provide information as to whether any of those students achieved the stated learning outcome or competency-whatever those might be. The solution for both of these problems should be a familiar drumbeat to faculty reading literature these days-rubrics, rubrics, rubrics. But it is important to understand that while much of that literature properly touts the benefits rubrics can have on students,${ }^{202}$ faculty should not ignore that rubrics are equally beneficial to the institution - and in fact, necessary to properly measure student learning gains. This extra step in preparing for an assessment sets the entire experience up for feedback as to how best improve the program of education. This investment allows faculty to use the new standards for positive gains.

It is important to note that the above data sets posit pulling information gleaned by direct assessments-such as exams, practical performance measures, clinical performances, or portfolios, to name a few. ${ }^{203}$ However, it is not enough for law schools to collect data on direct measures. Schools much also focus their information gathering and analysis on indirect measures, such as surveys of graduates or employers.

Surveys can be set up much like course evaluations with direct questions to alumni about the knowledge that they gained in the program, what they are doing with the knowledge gained in the program once employed, and what knowledge the graduate actually sees what they need once in practice but didn't get in the program. These types of concrete surveys are much more useful than many traditional surveys, which tend to focus on

${ }^{202}$ Susan M. Brookhart, How to Create and Use Rubrics for Formative Assessment and Grading, ACSD (Jan. 2013), http://www.ascd.org/publications/books/112001/chapters/What-Are-Rubrics-andWhy-Are-They-Important $\% \mathrm{C} 2 \% \mathrm{~A} 2 . \operatorname{aspx}$.

${ }^{203}$ Fisher, supra note 5, at 232. 
whether students had a "good" experience at the school and how they "felt" about their education.

Likewise, targeted questions can be posed through surveys to employers. By presenting an employer with a list of an institution's program learning outcomes to rate or rank and asking directly what skills employers need from the graduates, law schools can get additional metrics to determine whether your program is on target. ${ }^{204}$

Many of the preliminary pieces are already in place for schools to leverage their data-it is simply a matter of making small adjustments in grading or collecting information to have a wealth of information that can transform routine tasks to fantastic, useful information.

\section{CONCLUSION}

Based on extensive analysis of years of studies on feedback in schools, colleges, and workplaces, as well as student learning and teaching, the "simple truth is that everything works somewhere and nothing works everywhere." 205 Those schools or faculty looking for one easy path of setting learning outcomes and one set of assessments that will easily measure them, will be sorely disappointed. What works elsewhere-in other classrooms in their building, or in other universities, state or nationwide-may not work for them and shouldn't be coopted. Each course, program, and program of study needs to put in the hard work to craft a plan that will truly benefit their students.

But even for those who embrace that they must set their own path, the temptation to do so as simply or as technically correct as possible is strongas lawyers, we see a standard, and we want to meet the standard. We must not view these standards as ones to meet, but rather ones to use. These tips and ideas are meant to help those faculty reshape their attitudes about education and fully use the tools to make it as an effective experience as possible for our students.

204 Id at 232-33.

205 Wiliam, supra note 130 , at 19. 